\title{
Kulttuurienvälisten parisuhteiden relationaalinen dialektiikka
}

\section{Carine Cools}

Lektio praecursoria puheviestinnän väitöskirjaksi tarkoitetun tutkimuksen Relational Dialectics in Intercultural Couples' Relationships tarkastustilaisuudessa Jyväskylän yliopistossa 19.12.2011. Vastaväittäjänä toimi dosentti Fred Dervin (Turun yliopisto) ja kustoksena professori Maarit Valo.

Yhä useammat ihmiset muuttavat elämänsä aikana ulkomaille esimerkiksi henkilökohtaisista syistä tai opiskelun tai työn vuoksi. Nämä lyhyemmät tai pidemmät ulkomailla vietetyt ajanjaksot sijoittuvat yleensä elämänvaiheeseen, jossa ihmiset etsivät elämänkumppania tai ovat perustamassa perhettä. Siksi nykyisin on paljon yleisempää kuin muutama vuosikymmen sitten, että puolisoksi tai elämänkumppaniksi löytyy henkilö, jolla on erilainen kulttuuritausta.

Kulttuuritaustoiltaan erilaisten henkilöiden parisuhteen erityislaadusta ei kuitenkaan ole paljon tutkimustietoa, varsinkaan Euroopasta. Tiedetään kuitenkin, että vuorovaikutus ja viestintästrategiat, jotka ovat keskeisiä kaikissa ihmissuhteissa ja parisuhteissa erityisesti, vaikuttavat parisuhteen osapuolten hyvinvointiin.

Väitöskirjassa kulttuurienvälisten parien elämää ja kokemuksia lähestytään Baxterin ja Montgomeryn (1996) relationaalisen dialektiikan (relational dialectics) näkökulmasta. Tätä teoreettista lähestymistapaa on perinteisesti käytetty kulttuuritaustoiltaan samanlaisten parien vuorovaikutuksen tarkasteluun, mutta tässä tutkimuksessa sitä sovelletaan kulttuurienvälisten parisuhteiden kontekstissa. Relationaalisen dialektiikan lähestymistapa eroaa varsin paljon sellaisista aiemmista tarkastelutavoista, jotka kuvaavat ihmissuhteita erilaisten selkeästi alkavien ja loppuvien vaiheiden avulla. Relationaalisessa dialektiikassa nähdään, että jännitteet (suhteessa ilmenevät ristiriidat) ovat keskeinen piirre ihmissuhteissa, joten ne eroavat siksi käsitteenä konflikteista tai ongelmista. Suhteita dialektisesti tarkasteltaessa ajatellaan, että kaikissa ihmissuhteissa on sisäsyntyisiä jännitteitä vastakkaisten tai ristiriitaisten voimien välillä. Nämä dialektiset jännitteet ja se, kuinka suhteen osapuolet niihin reagoivat, ovat keskeisiä tekijöitä selittämään sitä, kuinka suhteet toimivat ja kuinka ne muuttuvat ajan myötä.

Väitöskirja tarkastelee romanttisessa suhteessa eläviä heteroseksuaalisia pareja, joiden osapuolet ovat kulttuuriselta taustaltaan erilaisia. Tutkimus on kvalitatiivinen, ja sen päätarkoituksena on kuvata ja ymmärtää kulttuurienvälis- 
ten parien suhteita Suomessa relationaalisen dialektiikan näkökulmasta. Tutkimuksen kohteena ovat ne haasteet, joita kulttuurienväliset parit kohtaavat.

Tutkimuskysymykset ovat seuraavat:

1) Mitä sisäisiä ja ulkoisia relationaalisia dialektisia jännitteitä kulttuurienväliset parit kokevat suhteessaan?

2) Millaisia kulttuurienvälisyyteen liittyviä dialektisia jännitteitä parit kohtaavat suhteessaan?

3) Kuinka kulttuurienväliset parit näkevät erilaisten kulttuuritaustojensa vaikuttavan parisuhteeseen?

Tutkimuskysymykset tarkastelevat kulttuurienvälisten parisuhteiden sosiaalisen todellisuuden merkityksellisiä tekijöitä kuten tietoa, ymmärrystä, näkemyksiä ja kokemuksia, joita osallistujat ilmaisevat haastatteluissa.

Aineistonkeruumenetelmänä käytettiin useiden erityyppisten haastattelujen yhdistelmää (multiple interviews). Useiden haastattelutapojen käyttäminen lisää mahdollisuutta saada monipuolisia ja kattavia tutkimustuloksia. Tutkimuksessa haastateltiin kulttuurienvälisiä pareja kolmessa ryhmässä, kutakin ryhmää eri haastattelumenetelmällä: teemahaastatteluihin osallistui 5 paria (10 osallistujaa), käsitekarttahaastatteluihin 6 paria (12 osallistujaa) ja sähköpostihaastatteluihin 7 paria (14 osallistujaa).

Tutkimusaineisto analysoitiin kvalitatiivisesti ja pääosin induktiivisesti. Aineiston pelkistämisen ja koodauksen avulla muodostettiin laajemmat teemat, jotka järjestettiin kategorioihin dialektisen näkökulman pohjalta.

\section{Tulokset ja päätelmät}

Tutkimuksen tuloksena nousi selvästi esiin, että kulttuurienväliset parit kokevat parisuhteessaan sekä suhteen sisäisiä että ulkoisia dialektisia jännitteitä (internal and external dialectical tensions). Nämä jännitteet vastaavat Baxterin ja Montgomeryn (1996) relationaalisen dialektiikan typologian jännitteitä.

Parien kertomusten pohjalta puolisoiden erilaiset kulttuuriset taustat näkyvät parisuhteessa esimerkiksi neuvotteluina, jotka koskevat 1) lomia, ystäviä, uskontoa, perinteitä ja juhlia, 2) lasten kasvattamista ja koulutusta, 3) arvoja ja sukupuoleen liittyviä kysymyksiä sekä 4) sopeutumista. Lisäksi kulttuurienvälisiin parisuhteisiin heijastuu se, kuinka edellä mainittujen neuvottelujen päätökset hyväksytään laajemmassa sosiaalisessa verkostossa.

Aineiston pohjalta määriteltiin kuusi kulttuurienvälisten parisuhteiden dialektista voimaa (intercultural relational dialectical forces): 1) jatkuva uudelleenneuvottelu, 2) kulttuurinen identiteetti ja kuuluminen, 3) lisääntynyt herkkyys 
eroja ja yhtäläisyyksiä kohtaan, 4) sosiaalinen valta, 5) sosiaalinen tuki ja 6) epävarmuus. Nämä voimat perustuvat ensinnäkin sisäisiin ja ulkoisiin relationaalisiin dialektisiin jännitteisiin. Toiseksi ne pohjautuvat kulttuurienvälisten parien näkemyksiin siitä, kuinka heidän kulttuuriset taustansa heijastuvat heidän parisuhteeseensa. Kolmanneksi ne perustuvat kulttuurienväliseen dialektiikkaan, johon kuuluvia dialektisia jännitteitä ovat esimerkiksi erilaisuus-samanlaisuus, yksilöllinen-kulttuurinen, henkilökohtainen-sosiaalinen, etuoikeutettu asemaepäedullinen asema, staattinen-dynaaminen ja nykyisyys/tulevaisuus-historia/ menneisyys.

\section{Sisäiset relationaaliset dialektiset jännitteet}

Sisäisellä tasolla sopeutumiseen liittyvät dialektiset jännitteet (kuten jännite sen välillä, ollaanko liiallisesti yhdessä vai pyritäänkö olemaan erillään) ovat yhteyksissä tuen käsitteeseen. Tuki voidaan joko hyväksyä, jättää huomiotta tai torjua, mikä aiheuttaa jännitettä suhteessa tukea tarjoavaan kumppaniin. Parit kokevat saavansa tukea sekä puolison että sosiaalisen verkoston kanssa käydystä vuorovaikutuksesta. Tuki auttaa heitä hallitsemaan epävarmoja tilanteita ja selviytymään stressiä aiheuttavissa olosuhteissa. Tuki on äärimmäisen tärkeää erityisesti juuri kulttuurienvälisissä suhteissa, koska kulttuuriseen sopeutumiseen liittyy sekä aiempien tukiverkostojen hajoaminen että haaste kehittää uusia verkostoja.

Ennustettavuuden ja uutuuden väliseen jännite tulee ilmi siten, että kulttuurienväliset parit luottavat suhteidensa kestävyyteen, mutta he myös ilmaisevat haluavansa spontaaniutta, yllätyksiä ja romantiikkaa. He kokevat epävarmuutta sopeutumiseen ja tulevaisuuteen liittyvissä asioissa, mikä vaikuttaa olevan erityistä juuri kulttuurienvälisille pareille. Parien epävarmuus omasta tulevaisuudesta näkyy eniten siinä, että heidän on vaikea tehdä päätöksiä siitä, missä asua, mistä etsiä töitä, kuinka ylläpitää perinteitä ja kuinka tehdä päätöksiä tai pitkän ajanjakson suunnitelmia. Nämä erityispiirteet liittyvät kulttuurienväliseen monimuotoisuuteen ja kontekstuaaliseen aika-tila-kronotooppiin (contextual time-space chronotope). Esimerkiksi sen sijaan, että pohdittaisiin muuttoa kaupungista tai kylästä toiseen, kulttuurienväliset parit miettivät muuttoa kahden maan tai maanosan välillä.

Avoimuuden ja sulkeutuvuuden välistä jännitettä tarkasteltaessa huomataan, että kulttuurienvälisten parien keskinäistä avoimuutta voidaan pitää keinona saada tukea. Tämän jännitteen kautta voidaan myös päästä käsiksi kulttuurienvälisten parisuhteiden perusolemukseen.

\section{Ulkoiset relationaaliset dialektiset jännitteet}

Ulkoisella tasolla sisältyneisyyden ja eristyneisyyden väliseen jännitteeseen liittyviä tekijöitä ovat 1) tarve saada tukea sukulaisilta, ystäviltä ja tuttavilta, 2) sopeutuminen ja kuuluminen, 3) parisuhteen vaarantava liiallinen osallistuminen sosiaalisiin verkostoihin, 4) sosiaalisista verkostoista poissuljetuksi tulemi- 
nen ja 5) sosiaalisten verkostojen ulkopuolelle jättäytyminen. Kulttuurienvälisillä pareillahan on yleensä lähettyvillään vain toisen puolison perhe. Siksi he eivät voi aina laskea samanlaisen tuen varaan kuin samasta kulttuurista tulevilla pareilla yleensä on. Tämä jännite, ja tunne johonkin verkostoon kuulumisesta tai kuulumattomuudesta, nousee joko kokemuksesta, että sosiaaliseen ympäristöön kuuluvat ihmiset eivät jollakin tavoin hyväksy, tai siitä, että ei ole sosiaalista verkostoa tai työtä.

Suhteessa konventionaalisuuden ja ainutlaatuisuuden väliseen jännitteeseen kulttuurienväliset parit pitävät itseään ja parisuhteitaan melko tavallisina, esimerkiksi koska he käyttäytyvät perinteisten parisuhdekäsitysten mukaisesti. Kulttuurienvälisten parisuhteiden ainutlaatuisuus liittyy näiden suhteiden rakentaviin ominaisuuksiin, kuten siihen, että erilaisuutta vaalitaan ja se nähdään myönteisenä asiana. Ainutlaatuisuus ilmenee myös siinä, että kulttuurienväliset parit eroavat yksikulttuurisista pareista ja että ulkopuoliset kokevat parien jotkut erityiset ominaisuudet, kuten vuorovaikutustyylin tai muut näkyvät piirteet, yleisestä poikkeavana.

Ilmaisemisen ja salaamisen väliseen jännitteeseen liittyen kulttuurienvälisten parien halua ilmaisemiseen motivoi heidän tarpeensa jakaa asioita ja nauttia seurasta sekä tarve luoda sosiaalisia kohtaamisia, joissa voi turvallisesti avautua. Tämä ei ole aina mahdollista parisuhteen sille osapuolelle, joka ei osaa puhua asuinmaan kieltä ja joka kokee tämän haittaavana. Parien päähuolenaihe tähän jännitteeseen liittyen on säilyttää ei-suomenkielisen puolison äidinkieli, koska sen ansiosta on mahdollista olla vuorovaikutuksessa lasten ja sukulaisten kanssa. Parien molemmat osapuolet ylläpitävät tietoisesti äidinkieltään, koska he ymmärtävät sen olevan ainoa keino jakaa asioita oman sosiaalisen verkoston kanssa.

\section{Kulttuurienvälisten parien kulttuuristen taustojen heijastuminen parisuhteeseen}

Kulttuurienvälisten parien kulttuuristen taustojen vaikutukset parisuhteeseen ovat moninaisia. Tuloksissa huomiota herättävintä, vaikkakaan ei yllättävintä, ovat kulttuurienvälisten parien käymät jatkuvat neuvottelut, jotka näyttävät määrittävän heidän elämäänsä niin sisäisesti kuin ulkoisestikin. Nämä neuvottelut vaativat toistuvaa päätösten ja kompromissien tekemistä lähestulkoon kaikesta. Lisäksi tuloksissa näkyy sopeutumisen ongelmallisuus, sillä sopeutumiseen liittyy kysymys vallasta ja epäedullisesta asemasta, kun toinen puoliso on aina heikompi osapuoli vuorovaikutustilanteissa.

Kulttuurienväliset parit kohtaavat toistuvasti kieleen liittyviä kysymyksiä. Kielitaidon puutteen ja uuden kielen opettelemisen välttämättömyyden koetaan estävän tai vaikeuttavan ei-suomalaisen osapuolen mahdollisuuksia osallistua kokonaisvaltaisesti suomalaiseen yhteiskuntaan. Kieli ja sen merkitykset vaikuttavat voimakkaasti kulttuurienvälisten parien jokapäiväiseen elämään. Vai- 
kuttavia tekijöitä ovat määrätietoinen kielenopiskelu, vähintään kahden kielen käyttäminen päivittäin perheessä sekä oman äidinkielen menettämisen tuska. Kieliasioihin liittyy myös vahvoja tunteita tuen antamisesta ja saamisesta.

Parit kertoivat sisällyttämiseen, poissulkemiseen ja eristyneisyyteen liittyvistä kokemuksista, ja he sivusivat myös kuulumisen kysymyksiä. Kuulumisen teema ilmenee esimerkiksi identiteetin etsinnän, näkyvyyden, erilaisuuden, juurettomuuden ja ylirajaisuuden kokemuksissa. Ei-suomalaiset puolisot pohtivat kulttuurista identiteettiään siitä näkökulmasta, että he ovat läsnä suomalaisessa kulttuurissa ja osallistuvat siihen, mutta kysymys koskettaa heitä myös heidän ollessaan kotimaassaan. Identiteetin etsiminen koskee myös parien suomalaisia osapuolia, koska he ovat kulttuurienvälisessä parisuhteessa ja he ovat oleskelleet puolisonsa kotimaassa ja kulttuurissa.

Jatkuvat uudelleenneuvottelut puolisoiden sekä parin ja heidän sosiaalisten verkostojensa välillä ovat tekijä, joka yhdistää parien kuvauksia siitä, miten heidän kulttuuriset taustansa heijastuvat parisuhteeseen.

\section{Kulttuurienvälisten parisuhteiden dialektiset voimat}

Tutkimusaineistosta löydettiin kuusi kulttuurienvälisten suhteiden dialektista voimaa: 1) jatkuva uudelleenneuvottelu, 2) kulttuurinen identiteetti ja kuuluminen, 3) lisääntynyt herkkyys eroja ja yhtäläisyyksiä kohtaan, 4) sosiaalinen valta, 5) sosiaalinen tuki ja 6) epävarmuus. Kaikki nämä voimat ovat yhteydessä toisiinsa.

Jatkuva uudelleenneuvottelu on kaikenkattava voima, jonka kautta kaikki muut voimat toteutuvat, mutta se on myös itsenäinen ja riippumaton. Tämä voima syntyy parin keskinäisestä viestinnästä, ja se määrittää heidän parisuhteensa kulttuurienvälisyyttä.

Kulttuurisen identiteetin ja kuulumisen voima liittyy uuteen ympäristöön sopeutumiseen ja kuulumiseen liittyvien tunteiden kanssa elämiseen. Identiteetin etsiminen ja kuuluminen merkitsevät myös sitä, että etsitään tasapainoa parisuhteessa sekä perheen ja ystävien välillä. Tämä voi olla pareille ajoittain huomattava haaste.

Lisääntynyt herkkyys eroja ja yhtäläisyyksiä kohtaan on luontaisesti tunnusomaista kulttuurienvälisille parisuhteille. Tämä herkkyys kehittyy, kun parit jatkuvasti neuvottelevat eroista ja yhtäläisyyksistä.

Sosiaalinen valta viittaa vallan ilmenemiseen puolisoiden välisessä vuorovaikutuksessa sekä parien ei-suomalaisten osapuolten ja heidän sosiaalisen verkostonsa välillä. Tämä voima osoittaa puolisoiden aseman eli sen, ovatko he parisuhteessa vahvempi vai heikompi osapuoli. Sosiaalinen valta liittyy kieleen ja kielenkäyttöön.

Sosiaaliseen tukeen kuuluu tarve saada tukea ja rohkaisua sekä puolisolta että parisuhteen ulkopuolelta. Se liittyy usein kieleen ja on osoituksena siitä, 
kuinka merkityksellisiä ovat ne kulttuuriset erot, joita ei-suomalaiset puolisot joutuvat käsittelemään.

Epävarmuus nousee kulttuurienvälisiin parisuhteisiin olennaisesti kuuluvista epävarmuustekijöistä. Niitä ovat esimerkiksi epävarmuus tulevaisuuden suhteen, päättämättömyys ja mahdottomuus tehdä pitkän aikavälin suunnitelmia

Tutkimuksen tuloksilla on yhteiskunnallista merkitystä nykyajassa, koska ne lisäävät tietojamme ja ymmärrystämme parisuhdeviestinnästä kulttuurienvälisessä kontekstissa. Tutkimuksen tärkein havainto on, että kulttuurienväliset parit kokevat erityisiä kulttuurienvälisyyteen liittyviä dialektisia voimia, jotka ilmenevät jatkuvana uudelleenneuvotteluna ja sen kautta syntyvinä muina voimina. Tietoisuus näistä voimista tarjoaa mahdollisuuden syventää ymmärrystä kulttuurienvälisistä parisuhteista ja niihin liittyvistä kysymyksistä. Lisäksi tuloksia voidaan soveltaa kulttuurienvälisille pareille tarjottavassa ohjauksessa ja neuvonnassa. 